\title{
RELATIONSHIPS BETWEEN FORCE-FEEDING AND SOME PHYSIOLOGICAL PARAMETERS IN GEESE BRED FOR FATTY LIVER
}

\author{
J. JANAN ${ }^{*}$, L. BÓDI ${ }^{1}$, Gabriella ÁGOTA ${ }^{2}$, L. BÁRDOS ${ }^{2}$, P. RUdAS $^{3}$, J. KOZÁK ${ }^{1}$ \\ and Mária KARSAI \\ ${ }^{1}$ Goose Breeding Research Station, ${ }^{2}$ Department of Animal Physiology and Health, \\ University of Agricultural Sciences, H-2103 Gödöllő, Páter K. u. 1, Hungary; \\ ${ }^{3}$ Department of Physiology and Biochemistry, University of Veterinary Science, \\ H-1400 Budapest, P.O. Box 2, Hungary
}

(Received January 8, 1999; accepted June 24, 1999)

\begin{abstract}
The susceptibility of geese of different genotypes and sexes to forcefeeding, some plasma biochemical parameters (thyroid hormones, cholesterol, retinoids, total protein and albumin) of force-fed geese, and the relationship between force-feeding, fat storage and the above-mentioned parameters were studied. Sixty (30 male and 30 female) geese of three genotypes (Hungarian, Landes and their crossbred called Babat Hybrid) were divided in two groups at 12 weeks of age. Geese in one group ( 5 males and 5 females from each genotype) received mixed feeding ad libitum. Birds in the other group were force-fed with maize. After 3 weeks all birds were bled, blood samples were taken, and the abovementioned plasma parameters were determined. Thyroxine $\left(\mathrm{T}_{4}\right)$ levels were significantly lower in force-fed $(11.6 \pm 3.5 \mathrm{ng} / \mathrm{ml})$ than in control geese $(22.7 \pm$ $4.09 \mathrm{ng} / \mathrm{ml})$. Plasma triiodothyronine $\left(\mathrm{T}_{3}\right)$ level was also lower in the force-fed than in the control group, but the difference was not significant $(1.87 \pm 0.23 \mathrm{ng} / \mathrm{ml}$ and $2.11 \pm 0.28 \mathrm{ng} / \mathrm{ml}$, respectively). Plasma total protein (TP, $45.2 \pm 4.5 \mathrm{~g} / \mathrm{l})$, albumin (ALB, $16.51 \pm 2.8 \mathrm{~g} / \mathrm{l}), \beta$-carotene (BC, $3504 \pm 3107 \mu \mathrm{g} / \mathrm{l}$ ), retinol (ROL, $1160 \pm 505 \mu \mathrm{g} / \mathrm{l})$, retinyl palmitate (RP, $1745 \pm 405 \mu \mathrm{g} / \mathrm{l})$ and total cholesterol (TCh, $4.32 \pm 0.55 \mathrm{mmol} / \mathrm{l}$ ) levels were elevated in the force-fed group as compared to the control $(\mathrm{TP}=36.4 \pm 5.1 \mathrm{~g} / \mathrm{l}, \mathrm{ALB}=15.6 \pm 0.9 \mathrm{~g} / \mathrm{l}, \mathrm{BC}=1657 \pm$ $1681 \mu \mathrm{g} / \mathrm{l}, \mathrm{ROL}=687 \pm 375 \mu \mathrm{g} / \mathrm{l}, \mathrm{RP}=1398 \pm 607 \mu \mathrm{g} / \mathrm{l}$, and $\mathrm{TCh}=2.83 \pm$ $1.98 \mathrm{mmol} / \mathrm{l})$. All differences were significant except those found for albumin and $\beta$-carotene. No significant sex- or genotype-related effects were observed for these parameters.
\end{abstract}

Key words: Goose, force-feeding, thyroid hormones, cholesterol, retinoids, proteins

\footnotetext{
* Corresponding author: Janbaz Janan, Goose Breeding Research Station, University of Agricultural Sciences, H-2103 Gödöllö, Páter K. u. 1, Hungary; Fax: +36 (28) 410-892; E-mail: prudas@ns.univet.hu
} 
Force-feeding produces fatty liver. In response to overfeeding, hepatic lipogenesis increases. A large part of the hepatic lipids of palmipedes cannot be secreted, and these lipids are stored in the liver to provide energy during migr ation (Fournier et al., 1997). Increased lipogenesis and storage of fat in the liver result in the condition called liver steatosis. Adiposity is a complex process that depends upon genotype as well as environmental factors. The ability of fatty liver production presents significant variability among breeds or among ind ividuals within breeds.

Several endocrine hormones affect the regulation of intermediary metabolism, in which adipose tissue acts as a central nutrient pool. It is well known that thyroid activity is one of the most important factors in controlling both metabolic rate and lipogenesis (Langslow and Hales, 1969; Rudas and Scanes, 1983).

One of the best known effects of thyroid hormones is their influence on the metabolic state; therefore, these studies will focus on the role of thyroid hormone economy when adapted to altered feeding conditions (Bartha, 1993). Hypocaloric feeding alters the circulating concentrations of thyroid hormone (O'Brian et al., 1980). Carbohydrates (Cavalieri, 1980) and, to a lesser extent, protein but not fat are able to increase triiodothyronine $\left(\mathrm{T}_{3}\right)$ generation via increasing deiodinase e $\mathrm{n}$ zyme activity on the liver. After feed restriction a systematic drop was observed in serum $\mathrm{T}_{3}$ concentration (Klandorf et al., 1981). The increased fat content of is ocaloric feed alters thyroid hormone economy in chickens just like feed restriction (Bartha, 1993). In an overview of the effects of energy metabolism on growth in poultry, Rudas and Buyse (1994) suggested that the proportion of total metaboli zable energy used for maintenance was closely correlated with the deposition of protein or fat. According to long-standing findings in the field of retinoid research, the process of absorption of $\beta$-carotene (BC) and its conversion to vitamin A co mpounds are positively influenced by thyroxine $\left(\mathrm{T}_{4}\right)$ (Moore, 1957).

Hypothyroidism of the chicken is accompanied by liver hypertrophy and glycogen accumulation in the liver (Snedecor, 1968). No significant differences were found in total protein and resting $\mathrm{N}$ between different goose breeds (Szép et al., 1976). Although the effects of different feeding systems on thyroid hormones and the other above-mentioned physiological parameters are well documented, there is no information about the effect of force-feeding on the concentrations of these parameters. Studies on the effect of force-feeding on fat storage in the liver and abdominal cavity and on biochemical parameters such as thyroid hormone metabolism, plasma cholesterol, retinoids and proteins could provide a better i nsight into the origin of in situ liver steatosis. They could also reveal the effects of selection programs that include susceptibility to such metabolic changes.

The objective of the present study was to compare geese of different gen otypes and sexes for susceptibility to force-feeding and for some plasma biochem ical parameters (thyroid hormones, cholesterol, retinoids and proteins), and to study the relationships between force-feeding, fat storage and the measured parameters. 


\section{Materials and methods}

\section{Animals and treatments}

Sixty (30 male and 30 female) geese of three different genotypes (Babat Hungarian Upgraded, Babat Grey Landes and their crossbred, Babat Liver Hybrid) were reared under similar conditions until 12 weeks of age. At 12 weeks of age the geese were divided into two groups. Geese in one group (5 male and 5 female birds from each genotype) were fed a commercial goose-rearing diet (17\% crude protein) ad libitum. The other group was force-fed with maize ( $8 \%$ crude protein). Water was available to all birds ad libitum. Treatment was continued for 3 weeks. After 3 weeks all birds were bled and blood samples were taken into heparinized tubes, centrifuged and plasma was stored at $-20{ }^{\circ} \mathrm{C}$ until analysed for thyroxine $\left(\mathrm{T}_{4}\right)$, triiodothyronine $\left(\mathrm{T}_{3}\right)$, total protein (TP), albumin (ALB), $\beta$-carotene (BC), retinol (ROL), retinyl palmitate (RP), and total cholesterol (TCh).

\section{Analysis}

The plasma levels of $\mathrm{T}_{4}$ and $\mathrm{T}_{3}$ were determined from each blood sample by radioimmunoassay (RIA; Pethes et al., 1978). Total cholesterol was dete rmined using a commercial test kit (Reanal, Hungary) based on the enzymatic (CHOD-POD) methods of Carlson and Goldfarb (1977). Retinoid (ROL and RP) analysis was carried out according to our modified HPLC method described ea rlier (Kerti and Bárdos, 1999). Concentration of BC was measured in a similar a rrangement but detection was carried out at $450 \mathrm{~nm}$. Total protein level was measured by the biuret method (Koller and Kaplan, 1987). Plasma ALB determ inations were carried out by the modified bromocresol green (BCG) dye-binding technique (Bárdos and Oppel, 1986).

The body weight and the weight of the liver and abdominal fat pad of each slaughtered goose were also measured.

Data were expressed as mean and standard error of the mean (SEM). Stati stical analysis was done by Student's $t$-test.

\section{Results}

Since there were no significant genotype-related differences in the physiological parameters, the results are presented as averages for the control and the treated (forcefed) groups. The differences between the control group and the force-fed groups in body weight, abdominal fat pad weight and liver weight were significant (Table 1). All these parameters were higher in the force-fed groups compared to the controls. Th yroxine levels (Fig. 1) were significantly lower in the treated groups $(11.6 \pm 3.5 ; \mathrm{N}=23)$ than the control levels $(22.7 \pm 4.09 ; \mathrm{N}=21)$. There were no significant differences between the force-fed groups and the control groups in plasma $\mathrm{T}_{3}$ levels (Fig. 2). 
Table 1

Effect of force-feeding on body weight (BW), abdominal fat pad weight (AFPW) and liver weight (LW) of geese of different genotypes

\begin{tabular}{|c|c|c|c|c|c|c|c|}
\hline & & \multicolumn{2}{|c|}{$\mathrm{BW}(\mathrm{kg})$} & \multicolumn{2}{|c|}{ AFPW (g) } & \multicolumn{2}{|c|}{ LW (g) } \\
\hline & & Force-fed & Control & Force-fed & Control & Force-fed & Control \\
\hline \multirow{2}{*}{ Hungarian gander } & Mean & 4.3 & 3.2 & $627^{\mathrm{a}}$ & $115^{\mathrm{b}}$ & $137^{\mathrm{c}}$ & $109^{d}$ \\
\hline & $\pm \mathrm{SEM}$ & 0.3 & 0.2 & 93 & 23 & 91 & 18 \\
\hline \multirow{2}{*}{ Hungarian layer } & Mean & 3.5 & 3.0 & $484^{\mathrm{a}}$ & $173^{b}$ & $277^{\mathrm{cd}}$ & $118^{\mathrm{d}}$ \\
\hline & \pm SEM & 0.2 & 0.2 & 72 & 39 & 82 & 29 \\
\hline \multirow{2}{*}{ Landes gander } & Mean & 4.1 & 3.2 & $610^{\mathrm{a}}$ & $133^{\mathrm{b}}$ & $463^{c}$ & $107^{\mathrm{d}}$ \\
\hline & $\pm \mathrm{SEM}$ & 0.1 & 0.3 & 94 & 31 & 82 & 19 \\
\hline \multirow{2}{*}{ Landes layer } & Mean & 3.3 & 2.9 & $732^{\mathrm{a}}$ & $132^{\mathrm{b}}$ & $341^{\mathrm{c}}$ & $92^{\mathrm{d}}$ \\
\hline & \pm SEM & 0.2 & 0.1 & 128 & 31 & 35 & 33 \\
\hline \multirow{2}{*}{ Hybrid gander } & Mean & 4.0 & 3.4 & $716^{\mathrm{a}}$ & $142^{\mathrm{b}}$ & $258^{\mathrm{c}}$ & $112^{\mathrm{d}}$ \\
\hline & \pm SEM & 0.5 & 0.2 & 261 & 12 & 54 & 11 \\
\hline \multirow{2}{*}{ Hybrid layer } & Mean & 3.3 & 3.0 & $549^{\mathrm{a}}$ & $145^{\mathrm{b}}$ & $254^{\mathrm{cd}}$ & $107^{\mathrm{d}}$ \\
\hline & \pm SEM & 0.8 & 0.1 & 100 & 35 & 59 & 26 \\
\hline
\end{tabular}

$a, b$ : Means of AFPW designated with different letters are statistically different $(P \leq 0.05)$; c, d: Means of LW designated with different letters are statistically different $(\mathrm{P} \leq 0.05)$

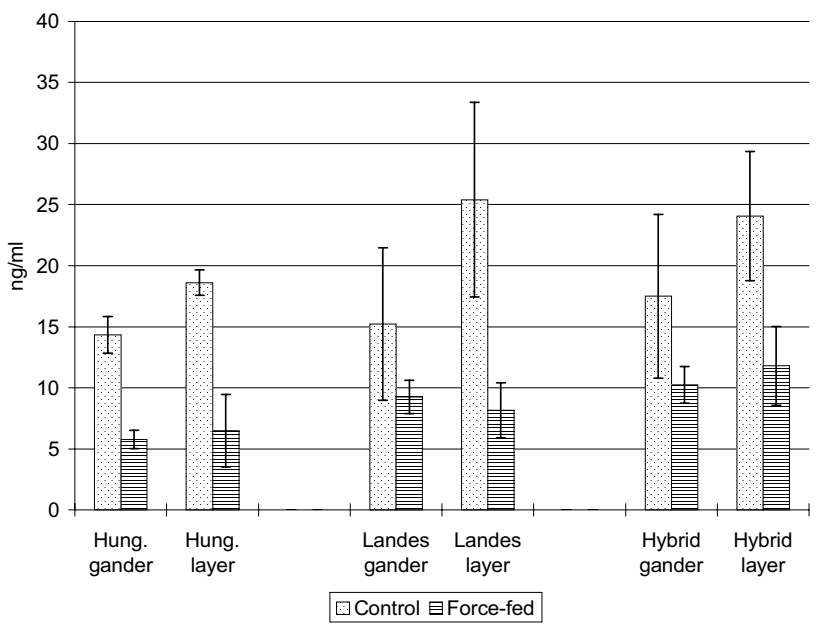

Fig. 1. Thyroxine concentration of the blood plasma

Table 2 summarises the results of plasma TP, ALB, BC, ROL, RP and TCh concentrations for the force-fed and the control groups. The plasma concentrations of $\mathrm{TCh}, \mathrm{BC}$ and ROL were elevated in the force-fed groups as compared to the controls. All differences were significant except those found for albumin and $\beta$-carotene. 


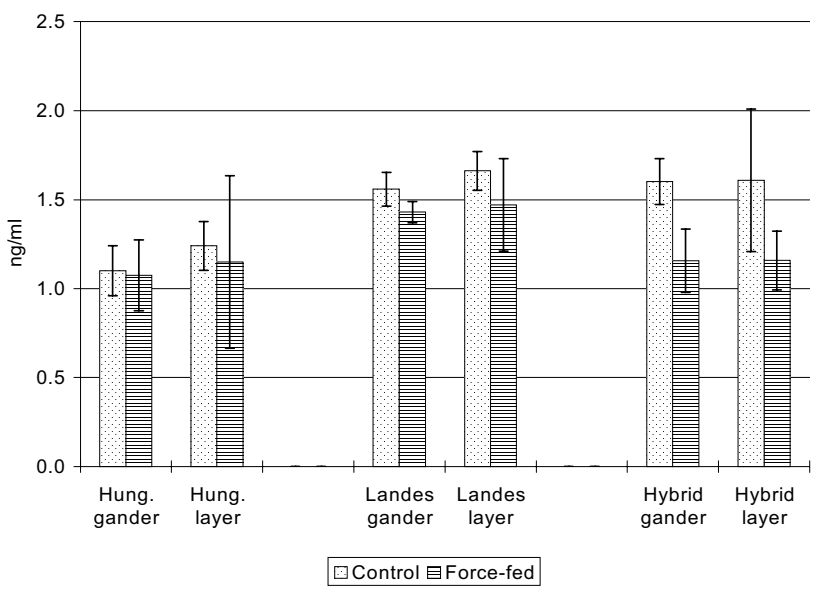

Fig. 2. Triiodothyronine concentration of the blood plasma

Table 2

Plasma protein and lipoid parameters

\begin{tabular}{lcccccc}
\hline \multirow{2}{*}{ Groups } & \multicolumn{5}{c}{ Blood parameters $(\bar{x} \pm$ SEM $)$} \\
\cline { 2 - 7 } & TP & ALB & BC & ROL & RP & TCh \\
\hline Control & $36.4 \pm 5.1$ & $15.6 \pm 0.9$ & $1657 \pm 1681$ & $687 \pm 375$ & $1398 \pm 607$ & $2.83 \pm 1.98$ \\
Force-fed & $45.2 \pm 4.5$ & $16.5 \pm 2.8$ & $3505 \pm 3108$ & $1160 \pm 506$ & $1745 \pm 405$ & $4.32 \pm 0.55$ \\
$t$-test & $\mathrm{P} \leq 0.001$ & NS & NS & $\mathrm{P} \leq 0.001$ & $\mathrm{P} \leq 0.05$ & $\mathrm{P} \leq 0.001$ \\
\hline
\end{tabular}

$\mathrm{TP}=$ total protein $(\mathrm{g} / \mathrm{l}) ; \mathrm{ALB}=$ albumin $(\mathrm{g} / \mathrm{l}) ; \mathrm{BC}=\beta$-carotene $(\mu \mathrm{g} / \mathrm{l}) ; \mathrm{ROL}=$ retinol $(\mu \mathrm{g} / \mathrm{l}) ; \mathrm{RP}=$ retinyl palmitate $(\mu \mathrm{g} / \mathrm{l}) ; \mathrm{TCh}=$ total cholesterol $(\mathrm{mmol} / \mathrm{l}) ; \mathrm{NS}=$ non-significant

No significant sex- and genotype-related differences could be demo nstrated for these parameters.

\section{Discussion}

Fatty liver syndrome in laying hens is an unresolved metabolic disease (Meijering, 1979). This syndrome is first of all associated with the consumption of excess energy. According to the literature, the syndrome is a manifestation of the lack of synchronism between hepatic lipid synthesis and secretion (Butler, 1976; Hansen and Walzam, 1993; Walzam et al., 1993). Shapira et al. (1978) noted a pronounced breed effect in response to overfeeding.

Indeed, liver steatosis in waterfowl is also based on the above factors. In these species, however, it is the explicit goal of the farmers to take advantage of the natural susceptibility of waterfowl to steatosis and of their ability to produce 
fatty liver. In goose, liver weight may increase more than 10 -fold or up to $10 \%$ of the body weight (Hermier et al., 1994). According to Walzam et al. (1993), s erum enzyme activities indicate that overfed hens, unlike overfed geese, retain hepatocellular membrane integrity.

As regards genotype, Tóth (1990) observed that the Landes (Babat Grey Landes) had better ability to produce fatty liver than the Babat Hungarian U pgraded. Fournier et al. (1997) also found that liver weight was $100 \%$ higher in Landes geese than in Poland geese. They found that the plasma concentration and triglyceride content of hepatic lipoproteins (VLDL and HDL) increased in parallel about one- to twofold, this effect being greater in Poland geese.

Concerning abdominal fat deposition, Cherry et al. (1978) stated that both nutritional and genetic factors appear to be involved. Wittmann (1997) observed that fattening performance, slaughter parameters, and meat characteristics of geese were less influenced by genotype, except liver and carcass weights that were largely affected by sex.

The information on thyroidal influence on body composition and fatness is relatively scarce. No reports have been published in the literature regarding the effect of force-feeding on circulating thyroid hormone levels. With regard to force-feeding the present data show that a marked decrease in plasma $\mathrm{T}_{4}$ and a non-significant decrease in $\mathrm{T}_{3}$ accompany the increase of fat deposition in the abdominal cavity and liver. However, subcutaneous fat deposition was not mea sured. Still, from the colour of the skin it was evident that deposition of fat in that tissue of force-fed geese did occur.

In fowl, thyroid deficiency is associated with adiposity while hyperth yroidism with decreased fat deposition (Wilson et al., 1983; Decuypere et al., 1987). Moreover, Stewart and Washburn (1983) found a negative correlation between plasma $T_{3}$ and carcass fat. $T_{3}$ decreases the fat content of birds (Decu ypere et al., 1987). In Japanese quails we observed that lines with higher abdom inal fat pad weight had lower plasma $\mathrm{T}_{4}$ and $\mathrm{T}_{3}$ (Janan et al., 1994).

Cogburn (1991) reviewed the endocrine manipulation of body compos ition in broiler chickens and concluded that treatment of broilers with low levels of $\mathrm{T}_{3}$ increases lean body weight by $10-20 \%$ by reducing fat deposition and stimulating protein synthesis in the skeletal muscle.

Our data suggest that overfeeding may affect the central production of th yroid hormones, where production is under the control of a classical central fee dback regulation. Most of the circulating $\mathrm{T}_{3}$ comes from the extrathyroidal conversion of $\mathrm{T}_{4}$. It is possible that the peripheral hormone activation is less affected by force-feeding than the control regulation.

An enzymatic assay currently in use in clinical laboratories for measuring total serum cholesterol has been used for the determination of plasma TCh of geese. The values of TCh were significantly elevated in the force-fed group. 
These animals were characterised by lower plasma thyroid levels reflecting their metabolic status.

Marks and Washburn (1991) studied two lines of Japanese quails selected for high (H-PCHOL) or low (L-PCHOL) plasma cholesterol response to ACTH, and observed that quail in the L-PCHOL had significantly $(\mathrm{P} \leq 0.5)$ more abdominal fat.

Patients with overt hypothyroidism had elevated serum total cholesterol and triglycerides (Lam et al., 1986). In the present experiment, force-fed birds had lower blood $\mathrm{T}_{4}$ and $\mathrm{T}_{3}$ levels. Similarly, the TCh level was significantly increased in force-fed animals. It is well known that blood lipids are reduced in hyperthyroidism and greatly increased in hypothyroidism. Thyroid hormones stimulate lipolysis, especially triglyceride breakdown, and enhance cholesterol excretion into the bile, thus resulting in a lower blood cholesterol level (Dickson, 1984).

As regards the interaction between thyroid hormones, total cholesterol, a 1bumin, total protein and energy intake, previous experiments showed that 14 days before and on the day of parturition the serum level of thyroid hormones $\left(\mathrm{T}_{4}\right.$ and $\mathrm{T}_{3}$ ) decreased to a greater extent in cows fed $21 \%$ less energy than in control cows. Energy intake had little influence on the serum concentrations of albumin, total protein, IgG, total cholesterol, and nonesterified fatty acids (Pethes et al., 1985).

The process of absorption and the conversion of $\mathrm{BC}$ to vitamin $\mathrm{A}$ are infl $\mathrm{u}-$ enced by $\mathrm{T}_{4}$ (reviewed by Moore, 1957). In the case of hypercarotenaemia and/or carotenodermia the plasma level of $\mathrm{T}_{4}$ is low (Rojas-Hidalgo and Olmedilla, 1993). In the present case the force-fed geese had significantly lower thyroid hormone levels than the control birds. This is the possible cause of the elevated plasma BC levels seen in the force-fed group, because the amount of total carotenoid pigment in wet corn is $20-25 \mathrm{mg} / \mathrm{kg}$. This quantity consists of $15-20 \% \mathrm{BC}$ in average (Borenstein and Bunnel, 1966). Retinoids (ROL, RP) and protein (TP, ALB) ind icate the higher provitamin A (carotenoid) and protein source of maize and the lower metabolic rate of the treated animals. These findings concerning lipids are similar to results obtained on Romanov geese by Muglali et al. (1997).

In conclusion, observations on plasma thyroxine, triiodothyronine, total protein, albumin, $\beta$-carotene, retinol, retinyl palmitate, and total cholesterol le vels indicated that differences existed between the force-fed groups and the co ntrols. We may assume that the observed differences could be related to the di fferent sensitivity of geese to energy intake. There were no significant differences in the above-mentioned physiological parameters between the three genotypes, although according to the literature they differ in liver production ability. A ccordingly, since the genetic control of fatness is polygenic (Leclercq, 1988), and fatty liver production is caused by an increase in lipogenesis and fat storage, it seems that these parameters cannot be used as selection criteria for a higher quantity and quality of fatty liver in geese. 


\section{Acknowledgements}

This work was supported by the Hungarian Scientific Research Fund (OTKA) grants no. T 022718 and 16545, and by the Research and Development Fund for Hungarian Higher Education (FKFP, grant no. 0672).

\section{References}

Bartha, T. (1993): Thyroid hormone metabolism in broiler chickens as influenced by exogenous and endogenous factors. Dissertationes de Agricultura. Katholieke Universiteit Leuven, Fakulteit der Landbouwwetenschappen Afdeling Veeteelt. 161 pp.

Bárdos, L. and Oppel, K. (1986): Modified BCG-reagent for determination of serum albumin (in Hungarian). Laboratóriumi Diagnosztika 13, 123.

Borenstein, B. and Bunnell, R. H. (1966): Carotinoids: properties, occurrences and utilization in foods. Adv. Food Res. 15, 195-276.

Butler, E. J. (1976): Fatty liver disease in the domestic fowl: a review. Avian Pathol. 5, 1-14.

Carlson, S. E. and Goldfarb, S. (1977): A sensitive enzymatic method for determination of free and esterified tissue cholesterol. Clin. Chim. Acta 79, 575-582.

Cavalieri, R. R. (1980): Peripheral metabolism of thyroid hormones. Thyroid Today 3, 1-10.

Cherry, J. A., Siegel, P. B. and Beane, W. L. (1978): Genetic-nutritional relationship in growth and carcass characteristics of broiler chickens. Poultry Sci. 57, 1482-1487.

Cogburn, L. A. (1991): Endocrine manipulation of body composition in broiler chickens. Critical Reviews in Poultry Biology 3, 283-305.

Decuypere, E., Buyse, J., Scanes, C. G., Huybrechts, L. and Kuhn, E. R. (1987): Effect of hyper- or hypothyroid status on growth, adiposity and level of growth hormone, somatomedin $\mathrm{C}$ and thyroid metabolism in broiler chickens. Reprod. Nutr. Develop. 27, 555-565.

Dickson, W. M. (1984): Endocrine glands. Dukes' Physiology of Domestic Animals. In: Stevenson, M. J. (ed.) Comstock Publ. Ass., Cornell Univ. Press, Ithaca-London. pp. 731-771.

Fournier, E., Peresson, R., Guy, G. and Hermier, D. (1997): Relationship between storage and secretion of hepatic lipids in two breeds of geese with different susceptibility to liver steatosis. Poultry Sci. 76, 599-607.

Hansen, R. J. and Walzam, R. L. (1993): Avian fatty liver hemorrhagic syndrome: a comparative review. Adv. Vet. Sci. Comp. Med. 37, 451-468.

Hermier, D., Rousselot-Pailley, D., Peresson, R. and Sellier, N. (1994): Influence of orotic acid and estrogen on hepatic lipid storage and secretion in the goose susceptible to liver steatosis. Biochim. Biophys. Acta 1211, 97-106.

Janan, J., Rudas, P., Bartha, T. and Ludrovszky, F. (1994): Serum concentrations of thyroid hormones during egg laying in two types of Japanese quail (Coturnix coturnix japonica). Arch. Vet. Polon. 34, 249-260.

Kerti, A. and Bárdos, L. (1999): Storage of retinoids and beta-carotene in genital organs of Japanese quail. Acta Vet. Hung. 47, 95-101.

Klandorf, H., Sharp, P. J. and Macleod, M. G. (1981): The relationship between heat production and concentrations of plasma thyroid hormones in the domestic hen. Gen. Comp. Endocrinol. 45, 513-520.

Koller, A. and Kaplan, L. A. (1987): Total serum protein. In: Presce, A. J. and Kaplan, A. L. (eds) Methods in Clinical Chemistry. Mosby Co., St. Louis. pp. 1134-1138.

Lam, K. S., Chan, M. K. and Yeung, R. T. (1986): High-density lipoprotein cholesterol, hepatic lipase and lipoprotein lipase activities in thyroid dysfunction: effects of treatment. J. Med. 59, 513-521. 
Langslow, D. R. and Hales, C. N. (1969): Lipolysis in chicken adipose tissue in vitro. J. Endocrinol. 43, 285-294.

Leclercq, B. (1988): Genetic selection of meat-type chickens for high or low abdominal fat content. In: Leclerq, B. and Whitehead, C. C. (eds) Leanness in Domestic Birds: Genetic, Metabolic and Hormonal Aspects. Butterworth, London. pp. 25-40.

Marks, H. L. and Washburn, K. W. (1991): Body, abdominal fat, and testes weights, and line by sex interactions in Japanese quail divergently selected for plasma cholesterol response to adrenocorticotropin. Poultry Sci. 70, 2395-2401.

Meijering, A. (1979): Fatty liver syndrome in laying hens - An attempt to review. World's Poultry Sci. J. 35, 79-94.

Moore, Th. (1957): The Vitamin E. Elsevier Publ. Comp., Amsterdam-London-New York.

Muglali, O. H., Ergun, A., Dogan, S., Dibirdik, I., Nazaroglu, N. K., Guler, A. and Oba, G. (1997): Effect of force-feeding on fatty liver production and some blood parameters of native and Romanov geese. Turk. J. Vet. Anim. Sci. 21, 107-111.

O’Brian, J. T., Bybee, D. E., Burman, K. D., Osburne, R. C., Ksiazek, M. R., Wartofsky, L. and Georges, L. P. (1980): Thyroid hormone homeostasis in states of relative caloric deprivation. Metabolism 29, 757-766.

Pethes, G., Losonczy, S. and Rudas, P. (1978): Measurement of serum triiodothyronine by radioimmunoassay (in Hungarian, with English abstract). Magyar Állatorvosok Lapja 33, 177-182.

Pethes, G., Bokori, J., Rudas, P., Frenyó, V. L. and Fekete, S. (1985): Thyroxin, triiodothyronine, reverse-triiodothyronine, and other physiological characteristics of periparturient cows fed restricted energy. J. Dairy Sci. 68, 1148-1154.

Rojas-Hidalgo, E. and Olmedilla, B. (1993): Carotenoids. Internat. J. Vitam. Nutr. Res. 63, 265-269.

Rudas, P. and Buyse, J. (1994): Energy metabolism in poultry. In: Decuypere, E. and Nichelman, M. (eds) Leistungsphysiologie des Geflügels. G. Fischer Verlag, Jena. pp. 152-193.

Rudas, P. and Scanes, C. G. (1983): Influence of growth hormone on glucose uptake by avian adipose tissue. Poultry Sci. 62, 1838-1845.

Shapira, N., Nir, I. and Budowski, P. (1978): Response of lipogenic enzymes to overfeeding in liver and adipose tissue of light and heavy breeds of chicks. Br. J. Nutr. 39, 151-157.

Snedecor, J. G. (1968): Liver hypertrophy, liver glycogen accumulation and organ weight changes in radiothyroidectomized and goitrogen-treated chicks. Gen. Comp. Endocrinol. 10, 277-282.

Stewart, P. A. and Washburn, K. W. (1983): Variation in growth hormone, triiodothyronine (T3) and lipogenic enzyme activity in broiler strains differing in growth and fatness. Growth 47, 411-425.

Szép, I., Ernhaft, J. and Vass, L. (1976): Comparative examination on several physiological data of geese of different breeds (in Hungarian, with English abstract). Állattenyésztés 6, 555-567.

Tóth, S. (1990): Changes in the prolificacy and liver production of geese of the Babat Hungarian and Landes breeds in the past 20 years (in Hungarian, with English abstract). Állattenyésztés és Takarmányozás 39, 407-416.

Walzam, R. L., Simon, C., Morishita, T., Lowenstine, L. and Hansen, R. J. (1993): Fatty liver hemorrhagic syndrome in hens overfed a purified diet. Selected enzyme activities and liver histology in relation to liver haemorrhage and reproductive performance. Poultry Sci. 72, 1479-1491.

Wilson, H. R., Boone, M. A., Arafa, A. S. and Janky, D. M. (1983): Abdominal fat pad reduction in broilers with thyroactive iodinated casein. Poultry Sci. 62, 811-817.

Wittmann, M. (1997): Influence of age, sex ad genotype on fattening performance, slaughtering results and meat quality of geese on intensive feeding. $11^{\text {th }}$ European Symposium on Waterfowl. Nantes, France. pp. 561-568. 